\title{
Serum and colostral antibody production in cows immunized with recombinant human tumor necrosis factor
}

\author{
Randall Burton, ${ }^{1}$ Skaison Kim, Rutvij Patel, Michele Scola, Deborah Hartman, Daniel Tracey, \\ and Barbara S. Fox \\ Avaxia Biologics Inc., 128 Spring Street, Lexington, MA 02124
}

\section{ABSTRACT}

The use of hyper-immune bovine colostrum as a human therapeutic platform is an emerging technology with potential to deliver the efficacy of antibody therapeutics with the convenience and safety of oral or topical application. It is necessary to understand how the bovine immune system responds to immunization with foreign proteins, both in terms of the serum antibody response and the transfer of antigen-specific antibodies into the colostrum to enable efficient large-scale production of therapeutic antibodies. We have immunized 25 cows with recombinant human tumor necrosis factor (rhTNF) and measured the levels of rhTNF-specific antibodies in the serum and colostrum of these animals. We observed a decline of $84 \pm 9 \%$ in serum $\operatorname{IgG}_{1}$ concentrations in the final weeks of pregnancy that presumably reflects rapid transport of $\mathrm{IgG}_{1}$ into colostrum. The serum $\mathrm{IgG}_{2}$ levels remained constant, such that the serum $\operatorname{IgG}_{1}$ to $\operatorname{IgG}_{2}$ ratio was $1: 20$ at parturition. We observed substantial animal-to-animal variability in the levels of anti-rhTNF antibodies in both serum and colostrum samples. In particular, a subset of 4 cows had extraordinarily high colostral anti-rhTNF antibody production. Only a weak correlation was found between the peak serum anti-rhTNF activity and the colostral anti-rhTNF activity in these animals. The 4 cows with high colostral anti-rhTNF activities trended toward higher serum $\operatorname{IgG}_{1}$ loss relative to average colostral anti-rhTNF producers, but this difference was not statistically significant in this small sample. The high-antirhTNF-producing cows also exhibited a greater proportion of rhTNF-specific antibodies that bound to bovine $\mathrm{IgG}_{1^{-}}$and $\mathrm{IgG}_{2^{-}}$specific detection antibodies relative to the total anti-rhTNF immunoglobulin population. This finding suggests that the isotype distribution of the anti-rhTNF response is varied between individuals and

Received January 6, 2016.

Accepted February 28, 2016.

${ }^{1}$ Corresponding author: rburton0830@gmail.com genetic or environmental factors may increase the yield of antigen-specific colostral antibodies.

Key words: colostrogenesis, dairy cow, protein immunization, antibody isotype

\section{INTRODUCTION}

The immunological response of cattle to foreign antigens is of interest for both bovine and human health. For example, the immune response of pregnant or lactating cows to viral pathogens (Opdebeeck et al., 1988; van Drunen Littel-van den Hurk et al., 2013; Coelho et al., 2013; van Drunen Littel-van den Hurk et al., 2008) and mastitis-related bacterial infections (ThompsonCrispi et al., 2014; Smolenski et al., 2014; Boerhout et al., 2015) is of considerable importance to the dairy industry for the development of effective vaccines. Also, several groups have demonstrated the efficacy of bovine colostral immunoglobulin preparations in treating human diseases, primarily those caused by bacterial or viral pathogens (Brüssow et al., 1987; Brunser et al., 1992; Opekun et al., 1999; Ashraf et al., 2001; van Dissel et al., 2005; Otto et al., 2011; Steele et al., 2013). In all cases, it is critically important that the cows develop a strong immune response to the antigen(s) of interest and efficiently transfer those antibodies into the colostrum.

The phenomenon of immunoglobulin transfer from blood into early colostrum is well known, but the underlying molecular mechanisms are only partially understood. Prior to parturition, mammary epithelial cells begin to express an $\operatorname{IgG}_{1}$-specific receptor that is believed to be responsible for active transport of $\mathrm{IgG}_{1}$ antibodies into colostrum (Barrington et al., 1997), leading to colostral $\mathrm{IgG}_{1}$ concentrations of 50 to 100 $\mathrm{mg} / \mathrm{mL}$ that are significantly greater the concentrations typically found in serum $(10-20 \mathrm{mg} / \mathrm{mL})$. Other immunoglobulin isotypes ( $\operatorname{Ig} \mathrm{A}, \operatorname{IgM}$, and $\operatorname{Ig}_{2}$ ) are found in colostrum at much lower concentrations, comparable to serum levels, suggesting that these isotypes enter the colostrum through passive diffusion (Ostensson and Lun, 2008; Baumrucker and Bruckmaier, 2014). 
The bovine immune response to DNA, protein, and viral antigens has been studied to assess the relative importance of injection site (Boerhout et al., 2015), adjuvant (Jackson and Opdebeeck, 1995; Rajput et al., 2007; Kateregga et al., 2012), added immunomodulatory proteins (Manoj et al., 2004; Maue et al., 2004), and timing relative to conception (Kramski et al., 2012). However, these studies have typically been quite small, with 1 to 7 animals per group. Given that bovine populations are genetically diverse, even within the Holstein breed (Thompson-Crispi et al., 2014), it is expected that there will be greater variability in the overall immunoglobulin response and the isotype distribution of the antigen-specific antibodies than is observed in genetically identical inbred animals (Davern et al., 1987). In addition, the production of colostrum IgG is known to vary considerably between individual cows, with total $\mathrm{IgG}$ mass varying between $30 \mathrm{~g}$ to $>2 \mathrm{~kg}$ (Baumrucker et al., 2010). Understanding the variability between individual animals is crucial to the design of comparative studies, to select group sizes that will be adequately powered to address the question at hand.

We have carried out a detailed characterization of the bovine immune response to a recombinant human cytokine, tumor necrosis factor (rhTNF). Tumor necrosis factor is a regulator of innate and adaptive immune responses, plays a key role in inflammation and has been implicated in several autoimmune disorders (Tracey et al., 2008), including ulcerative colitis (UC). We have developed a polyclonal anti-rhTNF antibody purified from bovine colostrum as a potential novel treatment of inflammatory bowel disease, including UC (AVX-470). An anti-murine TNF analog of AVX-470 alleviated inflammation in a mouse model of UC (Bhol et al., 2013), and AVX-470 was well-tolerated in a recently completed phase 1b study in UC patients (Harris et al., 2014). The primary objective of this study is to further optimize the production of AVX-470. We analyzed the appearance of rhTNF-binding immunoglobulins in the serum and colostrum of 25 cows to assess inter-animal variability and evaluate potential predictors of cows capable of producing a high level of colostral anti-rhTNF activity.

\section{MATERIALS AND METHODS}

\section{Animal Selection and Care}

The in-life portion of the study was carried out at Lake Immunogenics (Ontario, NY). Twenty-five Holstein cows $>2$ yr old, at 75 to $80 \mathrm{~d}$ before parturition and with at least 1 prior lactation were sourced from local commercial dairy farms. Cows were housed and the study performed at the Lake Immunogenics
Inc. Association for Assessment and Accreditation of Laboratory Animal Care and Office of Laboratory Animal Welfare accredited facility in Ontario, New York. Lake Immunogenics complied with all USDA animal care regulations, and followed the Guide for the Care and Use of Laboratory Animals (NRC, 2011) and the Guide for the Care and Use of Agricultural Animals in Research and Teaching (FASS Inc., 2010) while conducting the study. All research was performed in an Association for Assessment and Accreditation of Laboratory Animal Care accredited facility using protocols and programs that were reviewed and approved by the Lake Immunogenics Institutional Animal Care and Use Committee. All animals were examined by a veterinarian before inclusion in the study and confirmed to be in good health and tested negative for bovine leukosis virus, Mycobacterium paratuberculosis, and Coxiella burnetii. Each cow was vaccinated against rabies, bovine respiratory syncytial virus, bovine viral diarrhea virus, parainfluenza virus, bovine rhinotracheitis, Escherichia coli, rotavirus, leptospirosis, colostridum, and vibrosis before start of the study. Upon arrival at the facility, animals were dried off, quarantined for $21 \mathrm{~d}$, and observed daily. The immunization and sample collection protocol (described below) was initiated at the end of the quarantine. All animals were monitored throughout the study for overall health and proper nutrition.

\section{Immunization Protocol and Sample Collection Timetable}

Each cow was immunized 3 times with $50 \mu \mathrm{g}$ of rhTNF (catalog \#CRT100C, Cell Sciences, Canton, MA), prepared by mixing $2 \mathrm{~mL}$ of $25 \mu \mathrm{g} / \mathrm{mL} \mathrm{rhTNF}$ with $0.5 \mathrm{mg} / \mathrm{mL}$ Quil-A adjuvant (Brenntag Biosector, Frederikssund, Denmark). Previous experiments in calves have shown that Quil-A produced the highest anti-rhTNF antibody titer of 5 adjuvants tested (QuilA, Montanide ISA-25, Montanide ISA-201, Emulsigen$\mathrm{D}$, or Emulsigen-BCL), and that 3 injections of $50 \mu \mathrm{g}$ of rhTNF was sufficient to induce a strong immune response (data not shown). The first immunization occurred 50 to $60 \mathrm{~d}$ before the expected parturition date for each animal. The second immunization was performed $3 \mathrm{wk}$ after the first, and the third injection occurred 2 wk after the second. Serum samples were collected immediately before each immunization, then once a week until parturition. A final serum sample was collected from each cow at parturition. Colostrum samples were collected from all cows twice a day for 3 d (a total of 6 milkings) beginning on the day of parturition. Serum and colostrum aliquots were stored at $-20^{\circ} \mathrm{C}$. A fresh aliquot was thawed before each ELISA experiment. 


\section{rhTNF-Binding ELISA Protocol}

The ELISA plates (Greiner high and medium binding 96-well plates, catalog \#M4436-40EA, SigmaAldrich, St. Louis, MO) were coated with $100 \mu \mathrm{L} /$ well of $1 \mu \mathrm{g} / \mathrm{mL}$ rhTNF (Cell Sciences) in bicarbonate/ carbonate buffer (catalog \#C3041, Sigma-Aldrich), washed and blocked with SuperBlock (catalog \#37536, Thermo Scientific, Waltham, MA). The plates were washed and treated with $100 \mu \mathrm{L} /$ well of sample. Serum and colostrum samples were analyzed in triplicate at $1: 100,1: 500$, and 1:2,500 dilutions in $10 \mathrm{~m} M$ sodium phosphate, $150 \mathrm{~m} M$ sodium chloride, $0.05 \%$ (vol/vol) polysorbate 20, $2 \%$ (vol/vol) SuperBlock, pH 7.4. Milk samples were analyzed at 1:10, 1:20, and 1:40 dilution. Spike recovery and linearity tests confirmed that sample matrix effects were not significant at these dilutions (data not shown). In addition, triplicate wells forming a standard curve were included on each plate using purified AVX-470 (Bhol et al., 2013). The plate was washed and probed with $100 \mu \mathrm{L} /$ well of $25 \mathrm{ng} /$ $\mathrm{mL}$ HRP-anti-bovine $\operatorname{IgG}\left(\mathrm{H}^{+} \mathrm{L}\right)$ antibody (catalog \#A10-115P, Bethyl Laboratories, Montgomery, TX). The plate was washed and incubated with $100 \mu \mathrm{L} /$ well TMB substrate (catalog \#00-2023, Life Technologies) for $15 \mathrm{~min}$ at room temperature, and quenched with $100 \mu \mathrm{L} /$ well 1\% (vol/vol) sulfuric acid (catalog \#320501, Sigma-Aldrich). The absorbance at $450 \mathrm{~nm}$ was recorded for each well.

The rhTNF-binding activities are reported as arbitrary units (AU) per milliliter to account for plate-toplate variability in the absorbance signal. An ELISA reference standard was prepared from an early batch of AVX-470 (referred to as TOX3-1) at $1.6 \mathrm{mg} / \mathrm{mL}$ and defined to be $1,000 \mathrm{AU} / \mathrm{mL}$. The absorbance values for triplicate measurements of each standard dilution were averaged and the mean absorbance versus AU per milliliter data were fit to a 5-parameter logistic function, which was then used to convert absorbance values from the sample and assay control wells to AU per milliliter values. Absorbance values that fell outside of the standard curve were reported as out of range and not included in any subsequent calculations. Assay control samples at nominal activities of 50 and $10 \mathrm{AU} / \mathrm{mL}$ were included in each plate without dilution. If the reported value for either sample was greater than $150 \%$ of the nominal value, or less than $50 \%$ of the nominal value, the data from that plate were not used for analysis, and the samples were run again on another plate.

\section{Total IgG Determination by Protein G Chromatography}

The total IgG in colostrum samples was determined by the area of the elution peak from a Protein G Sep- harose column on an ÄKTA Purifier chromatography system (GE Healthcare, Little Chalfont, UK). A standard curve was generated by preparing AVX-470 (Bhol et al., 2013) solutions at 0 to $10 \mathrm{mg} / \mathrm{mL}$. A $100-\mu \mathrm{L}$ injection loop was overfilled with diluted sample to ensure quantitative injection of $100 \mu \mathrm{L}$ of sample at the correct concentration. The standards were injected onto a column containing $3 \mathrm{~mL}$ of Protein G Sepharose FF (catalog \#17-0618-01, GE Healthcare), washed with 2 column volumes of $1 \times$ PBS, and eluted with 5 column volumes of $100 \mathrm{mM}$ sodium citrate, $\mathrm{pH} 2.5$. The elution peak area was found to be directly proportional to the load concentration for this concentration range (data not shown). Colostrum samples were diluted 25-fold with PBS and analyzed by the procedure used for the AVX-470 standards. The elution peak area was converted to IgG concentration using the AVX-470 standard curve.

\section{Determination of $\lg G_{1}$ and $\lg G_{2}$ Levels in Serum and Colostrum by ELISA}

Total bovine $\operatorname{IgG}_{1}$ and $\operatorname{IgG}_{2}$ concentrations were determined using ELISA reagent sets from Bethyl Laboratories $\left(\mathrm{IgG}_{1}\right.$ : catalog \#E10-116, $\operatorname{IgG}_{2}$ : catalog \#E10-117), following the protocols included with the kits. For determination of rhTNF-specific $\operatorname{IgG}_{1}$ and $\operatorname{IgG}_{2}$ antibodies, the anti-rhTNF ELISA procedure described above was used, except that the secondary antibody was replaced with either HRP-anti-bovine $\mathrm{IgG}_{1}$ (catalog \#A10-116P, Bethyl Laboratories) or HRP-anti-bovine $\mathrm{IgG}_{2}$ (catalog \#A10-117P, Bethyl Laboratories) and an isotype-purified reference standard was used. The $\operatorname{IgG}_{1}$ anti-rhTNF standard was purified from the first milking of cow \#6003, and the $\operatorname{IgG}_{2}$ anti-rhTNF standard was isolated from the serum collected from the same cow on the same day. Both standards were purified by a combination of Protein G affinity chromatography and diethylaminoethanol (DEAE) chromatography. Their isotypic purity (>95\%) was confirmed using the Bethyl Laboratories kits described above.

\section{Confirmation of Isotype ELISA Results by Mass Spectrometry}

Serum and colostral IgG were purified for mass spectrometry analysis by Protein G affinity chromatography. One milliliter of serum or colostrum was diluted with $9 \mathrm{~mL}$ of $1 \times$ PBS and the entire diluted sample was applied to a 3-mL Protein G Sepharose FF column on an ÄKTA Purifier chromatography system (GE Healthcare). The column was washed with 5 column volumes of $1 \times$ PBS and eluted with 2 column volumes of $100 \mathrm{~m} M$ sodium citrate, $\mathrm{pH}$ 2.5. Each 1-mL elution 
fraction was neutralized with $300 \mu \mathrm{L}$ of $1 M$ TrisCl, $\mathrm{pH}$ 9.0, and then buffer exchanged into $1 \times \mathrm{PBS}$ by 3 concentration and redilution cycles in an Amicon 15 spin filter (EMD Millipore catalog \#UFC903008, Darmstadt, Germany). Serum and colostral IgG were diluted to $30 \mathrm{mg} / \mathrm{mL}$ in $20 \mathrm{~m} M$ sodium acetate, $\mathrm{pH} 5.0$. Three microliters of diluted antibody was combined with $7 \mu \mathrm{L}$ of $0.5 \mathrm{M}$ sodium acetate, $8 \mathrm{M}$ guanidine hydrochloride, $50 \mathrm{mM}$ n-ethylmaleimide, $\mathrm{pH} 5.0$ to denature the protein and alkylate any free thiol groups. The samples were incubated for $16 \mathrm{~min}$ at room temperature. Four microliters of a $2 \mathrm{mg} / \mathrm{mL}$ stock of endoproteinases Lys-C (catalog \#90051, Thermo Scientific) was added, and the samples were incubated for $32.5 \mathrm{~h}$ at $37^{\circ} \mathrm{C}$. Each sample was reduced with Tris(2-carboxyethyl) phosphine hydrochloride added to a final concentration of $1 \mathrm{mM}$. The samples were desalted with C-18 spin columns (catalog \#89870, Thermo Scientific). The eluates were dried overnight and resuspended in $50 \mu \mathrm{L}$ of $0.1 \%$ formic acid in water. The samples were separated with a custom C-18 micro-capillary column and the eluted peptides analyzed with a LTQ OrbiTrap Velos mass spectrometer (Thermo Scientific). The mass spectrometry data were analyzed using Mascot software (version 2.5.0, Matrix Science, London, UK). Mascot was set up to search a database of all bovine proteins found in the National Center for Biotechnology Information nonredundant database (123,449 entries) assuming the digestion enzyme Lys- $\mathrm{C}$ with a fragment ion mass tolerance of $0.050 \mathrm{Da}$ and a parent ion tolerance of 10.0 ppm. Scaffold (version Scaffold_4.4.5, Proteome Software Inc., Portland, OR) was used to validate peptide identifications. Peptide identifications were accepted if they could be established at greater than $90.0 \%$ probability by the Peptide Prophet algorithm (Keller et al., 2002) with Scaffold delta-mass correction.

\section{RESULTS}

\section{Anti-rhTNF Activity in Colostrum and Milk Samples}

Twenty-five pregnant Holstein cows were immunized with 3 doses of rhTNF during the last 2 mo before their expected calving dates. Colostrum was collected twice daily for $3 \mathrm{~d}$ postparturition. As shown in Figure 1, panel A, 24 out of 25 cows produced measurable levels of anti-rhTNF antibody in their colostrum. The one exception (ear tag \#7060) gave birth shortly after the second immunization, and so did not receive the third immunization. All responding cows exhibited a similar time course of colostral anti-rhTNF expression, with the highest concentrations observed in the first colostrum sample, and less with each subsequent milking. Excluding the animal that did not receive all $3 \mathrm{rhTNF}$ immunizations, variability from animal to animal is substantial with a 20-fold difference in peak colostrum anti-rhTNF concentration between the highest and lowest activity colostrum samples. Also, a $\sim 20$-fold range was found in the total anti-rhTNF antibody activity in colostrum, calculated by adjusting for the volume of colostrum collected in each milking (Figure 1, panel B; Supplemental Materials and Table S1, http://dx.doi. org/10.3168/jds.2016-10863).

The variation in anti-rhTNF levels between cows (Figure 1, panel B) was not normally distributed. This was confirmed using the Shapiro-Wilk test $(P<0.01$; implemented in the Real Statistics Resource Pack software, release 4.3, www.real-statistics.com) and a quartile-quartile plot (data not shown). A distinct population of 4 cows produced an unusually high amount of rhTNF-specific antibodies in their colostrum relative to the other animals in the cohort. If the 4 cows with the highest anti-rhTNF levels were removed, the remaining data are normally distributed (Shapiro-Wilk, $P=$ 0.48). A series of additional analyses were performed on serum and colostrum samples to test hypotheses on the source of this difference.

It was possible that this subset of high-producing cows could have unusually high levels of total IgG in their colostrum. As shown in Figure 2, substantial variability in total IgG levels was present, with total amounts ranging from 200 to 2,000 g. Similar ranges have been observed in previous studies (Baumrucker et al., 2010). However, no correlation was found between total IgG and specific anti-rhTNF activity (Figure 2). The high-producing subset of cows does not have unusually high IgG production overall, but rather has a higher proportion of rhTNF-specific antibodies.

\section{Total Anti-rhTNF Activity in Serum Samples}

Serum anti-rhTNF activity was measured in each animal to assess the magnitude and time course of the immune response to the rhTNF immunizations, using the same ELISA protocol as was used with the colostrum samples. All animals had undetectable or very low levels of rhTNF-binding antibodies before receiving rhTNF or after the first immunization. As shown in Figure 3, anti-rhTNF levels appeared after the second and third immunizations, and peaked 1 to 2 wk after the final (third) immunization. Some cows gave birth either before or very shortly after the third immunization; in those cases it was not possible to follow the serum anti-rhTNF activities, as serum samples were only collected up to the day of parturition. In all cases where measurements could be taken, the anti-rhTNF titers began to decrease 2 wk after the third immunization. 
The correlation between peak serum and colostrum anti-rhTNF levels was weak $(r=0.17$, Figure 4$)$, suggesting that some of the variability in colostral antirhTNF activity can be explained due to the variable antibody response generated in each animal. However, the group of 4 animals with high colostral anti-rhTNF levels did not exhibit an unusually robust serum antirhTNF response (Figure 4). When the data from the high anti-rhTNF cows are taken out of the regression analysis, the correlation between serum and colostrum anti-rhTNF levels is higher $(r=0.32)$, and is statistically significant $(P<0.01$ by Fisher's z-transformation test; Press et al., 1992). Similar analyses demonstrated that the 4 cows with high anti-rhTNF activity in colostrum are not unusual with respect to colostrum volume, animal age, or time span between final immunization
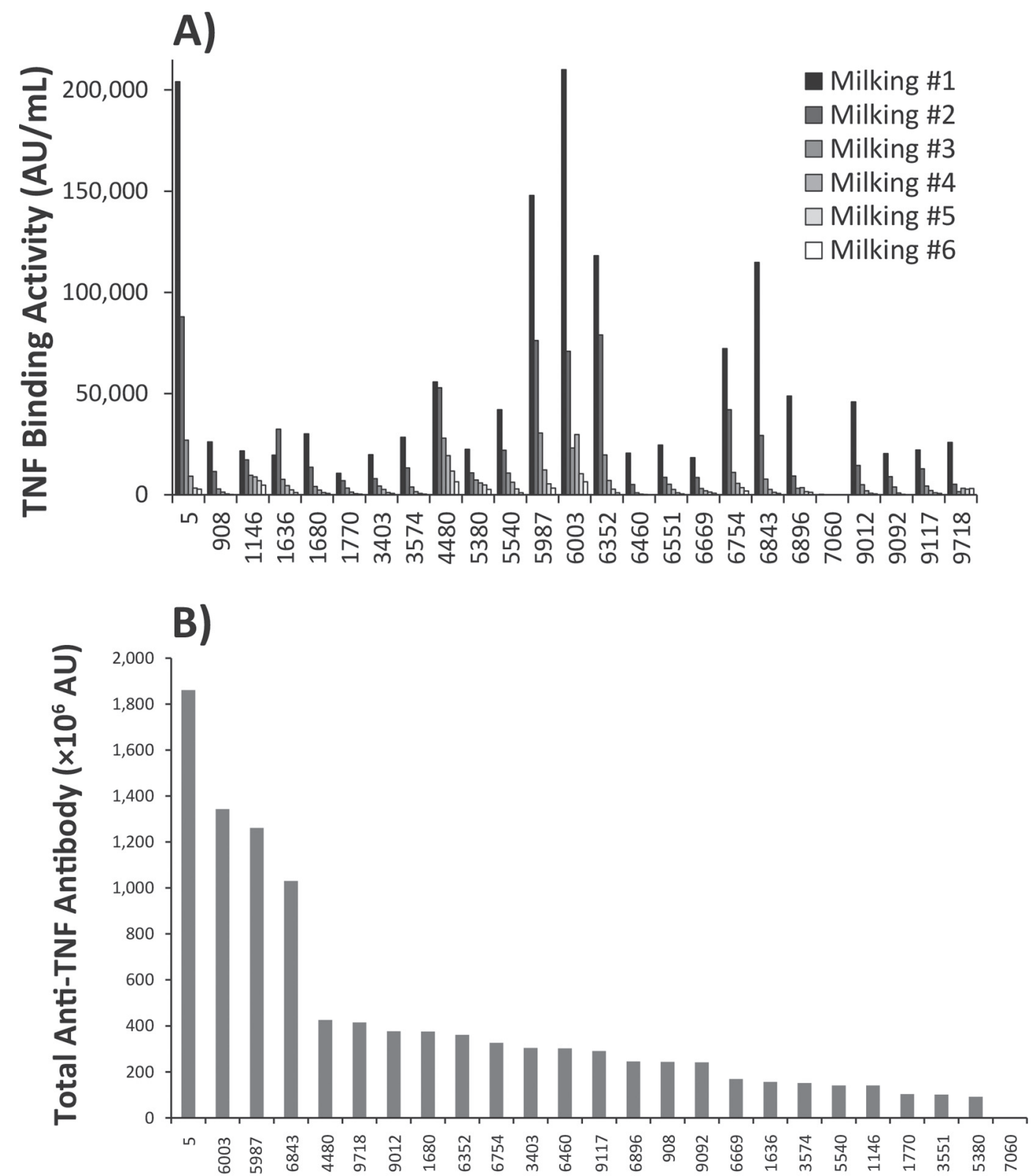

Ear Tag \#

Figure 1. The ELISA data for recombinant human tumor necrosis factor (rhTNF)-binding activity in colostrum samples from 25 cows immunized with rhTNF/Quil A injections during the final trimester of pregnancy. Each animal is identified by an ear tag number. Colostrum was collected from each cow twice daily for the first $3 \mathrm{~d}$ postparturition. The rhTNF-binding activity in each milking is represented by a shaded bar (milkings 1 to 6 from left to right within a tag no.). (A) Histogram of anti-rhTNF activities found in all 6 milkings for the 25 cows. The concentration of anti-rhTNF antibody, determined by direct ELISA, is shown by the height of each bar. (B) The total anti-rhTNF antibody in the first 3 milkings of each cow, calculated by multiplying the ELISA activity by the volume of colostrum collected at each milking. 


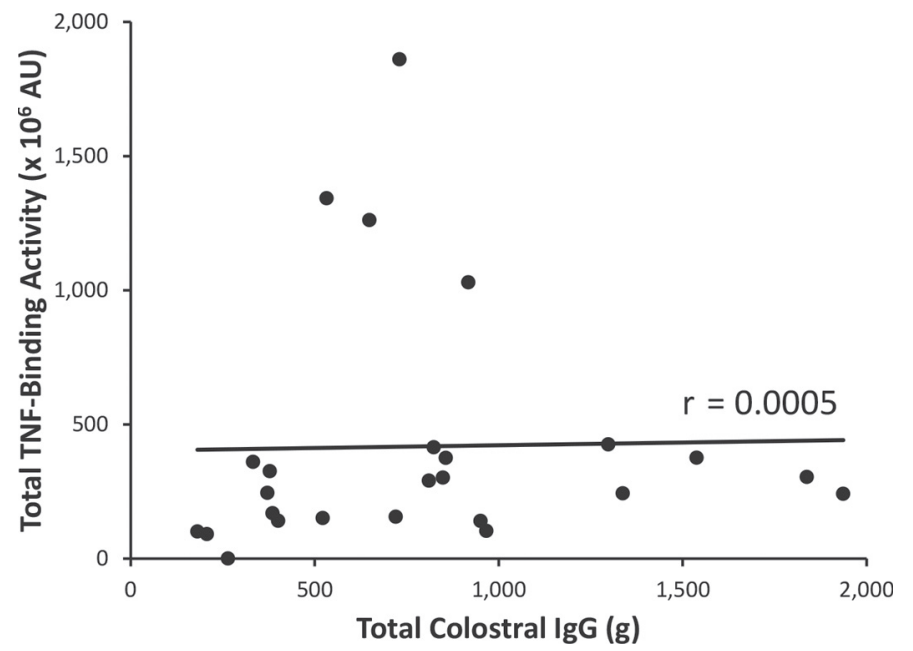

Figure 2. Comparison of total IgG and recombinant human tumor necrosis factor (rhTNF)-specific IgG levels in colostrum samples from 25 cows. Total IgG in the first 3 milkings was determined by comparison of the elution peak areas from a protein G column compared with a standard curve. The rhTNF-specific IgG fraction was determined by ELISA. Linear regression analysis (solid line) reveals no correlation between total and rhTNF-specific IgG.

and parturition (Supplemental text and Supplemental Table S1; http://dx.doi.org/10.3168/jds.2016-10863).

\section{Serum Total $\lg G_{1}$ and $\lg G_{2}$ Levels}

Because $\operatorname{Ig}_{1}$ is preferentially transferred from the bloodstream into colostrum (Barrington et al., 1997; Ostensson and Lun, 2008), we analyzed the serum isotype distribution of a subset of cows (the 4 cows with

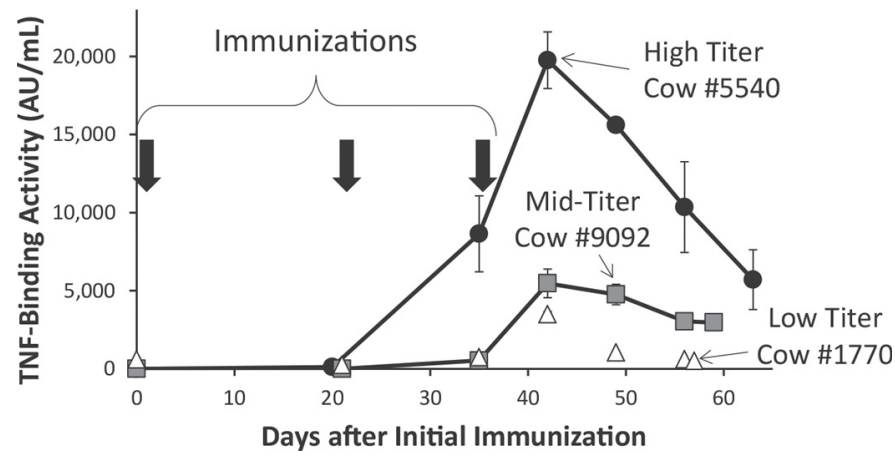

Figure 3. Serum recombinant human tumor necrosis factor (rhTNF)-binding activities versus time for representative cows. ELISA data for rhTNF-binding activity in serum samples from selected cows. Examples are shown of a cow with a relatively high peak anti-rhTNF activity (cow \#5540), a cow with a peak titer close to the median value for the 25-cow cohort (cow \#9092), and one with a relatively low titer (cow \#1770). Serum samples were collected before the first immunization (bleed \#1), before the second immunization $21 \mathrm{~d}$ later (bleed \#2), before the third immunization $14 \mathrm{~d}$ after that (bleed \#3), and weekly thereafter until the final serum sample was collected on the day of parturition (bleeds \#4-7). high levels of anti-rhTNF antibody in colostrum and 8 cows with average levels of anti-rhTNF antibody in colostrum but high anti-rhTNF levels in serum; Table 1). Total serum $\operatorname{IgG}_{1}$ levels at parturition of all 12 cows were very low relative to the levels of serum $\operatorname{IgG}_{2}$ (Table 1). Surprisingly, we observed an $84 \pm 9 \%$ decline in total serum $\operatorname{IgG}_{1}$ concentrations over the final 2 to 3 mo of pregnancy, which is substantially larger than has been previously reported (Sasaki et al., 1976). An example of this time-dependent decrease in one of the high-titer cows is shown in Figure 5. No significant difference was seen in the isotype distribution or decline over time when the 2 subpopulations of cows were compared.

\section{Serum Anti-TNF Ig $G_{1}$ and $\lg G_{2}$ Levels}

We also evaluated the isotype distribution of the anti-rhTNF serum antibody in a subgroup of 6 cows. As shown in Table 2, both $\operatorname{IgG}_{1}$ and $\operatorname{IgG}_{2}$ rhTNF-binding antibodies were produced in the serum from these cows, and the ratio of $\operatorname{IgG}_{1}$ to $\operatorname{IgG}_{2}$ varied from 17.4 to 0.41 . We observed a bias toward the production of $\mathrm{IgG}_{1}$ anti-TNF antibodies in 5 out of 6 cows, consistent with the isotype bias observed upon immunization with lysozyme (Thompson-Crispi and Mallard, 2012).

The isotype analysis was performed by ELISA using secondary antibodies specific for bovine $\operatorname{IgG}_{1}$ and

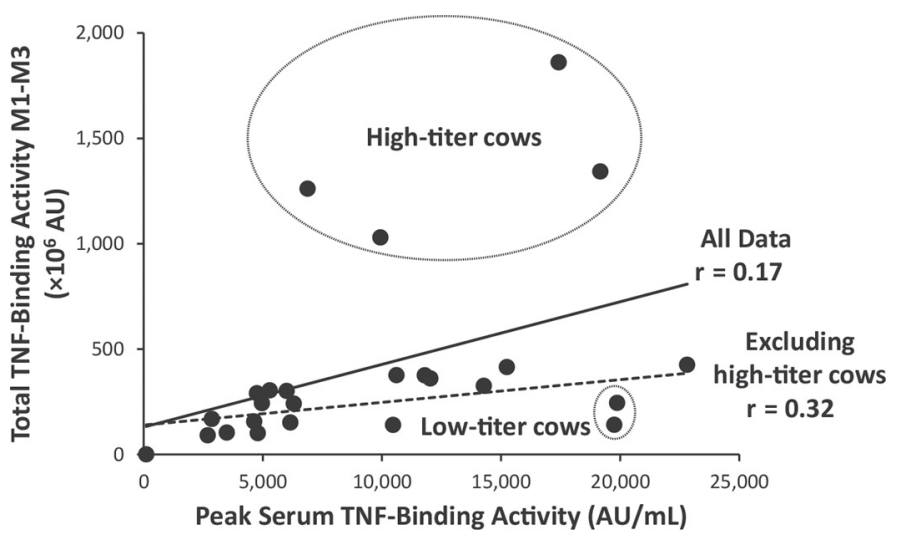

Figure 4. Correlation between serum and colostrum recombinant human tumor necrosis factor (rhTNF)-binding activities. Correlation of total anti-rhTNF antibody in colostrum versus peak serum titer in study. Each point represents the data for a single animal. The $\mathrm{x}$-axis is the peak serum anti-rhTNF concentration measured for that cow, and the $\mathrm{y}$-axis is the total anti-rhTNF activity found in the first 3 milkings for that cow. The total activity is determined by multiplying the anti-rhTNF concentrations measured by ELISA [in arbitrary units $(\mathrm{AU}) / \mathrm{mL}$ ] with the total volume of each milking (in $\mathrm{mL}$ ). The solid line shows a linear regression fit of this data. Four cows (enclosed in the upper circle) exhibited unusually high colostral anti-rhTNF activity compared with the rest of the cohort. The dotted line shows a linear regression fit of the data when those 4 cows are excluded from the analysis. The lower circle highlights 2 cows with very high serum anti-rhTNF antibody levels, but relatively low colostral anti-rhTNF activity. 
Table 1. Isotype analysis of total IgG in selected serum samples

\begin{tabular}{|c|c|c|c|c|}
\hline Ear tag \# & $\underset{(\mathrm{mg} / \mathrm{mL})}{\operatorname{Maximum}\left[\operatorname{IgG}_{1}\right]}$ & $\begin{array}{c}{\left[\mathrm{IgG}_{1}\right] \text { at }} \\
\text { parturition }(\mathrm{mg} / \mathrm{mL})\end{array}$ & $\begin{array}{c}{\left[\mathrm{IgG}_{2}\right] \text { at }} \\
\text { parturition }(\mathrm{mg} / \mathrm{mL})\end{array}$ & $\begin{array}{l}\% \text { decrease } \\
\text { in } \operatorname{IgG}_{1}\end{array}$ \\
\hline \multicolumn{5}{|c|}{$\begin{array}{l}\text { Cows with average rhTNF-binding } \\
\text { activity in colostrum }\end{array}$} \\
\hline 6551 & 3.11 & 0.40 & 20.38 & 87 \\
\hline 9718 & 4.35 & 0.74 & 16.89 & 83 \\
\hline 6754 & 21.23 & 2.19 & 31.58 & 90 \\
\hline 6896 & 6.30 & 2.20 & 17.80 & 65 \\
\hline \multicolumn{5}{|c|}{$\begin{array}{l}\text { Cows with high rhTNF-binding } \\
\text { activity in colostrum }\end{array}$} \\
\hline 5 & 10.17 & 1.03 & 18.14 & 90 \\
\hline 6003 & 8.86 & 0.54 & 24.50 & 94 \\
\hline 5987 & 10.05 & 1.17 & 24.04 & 88 \\
\hline
\end{tabular}

${ }^{1}$ rhTNF $=$ recombinant human tumor necrosis factor.

${ }^{2}$ Two-sided homoscedastic $t$-test between average- and high-colostrum titer groups.

bovine $\mathrm{IgG}_{2}$. The total immunoglobulin analysis was performed using a secondary antibody that reacts with the IgG heavy chain and the light chain common to all isotypes. Whereas in some cows the sum of specific $\operatorname{IgG}_{1}$ and $\operatorname{IgG}_{2}$ added up to or even exceeded the levels of total $\mathrm{Ig}$, in other cows the $\mathrm{IgG}_{1}$ and $\mathrm{IgG}_{2}$-specific response only accounted for a small percentage of the total anti-rhTNF response. Notably, the $\operatorname{IgG}_{1}$ and $\operatorname{IgG}_{2}$ levels had the highest correlation with total immunoglobulin in the cows with the high levels of colostral anti-rhTNF, although the ability to draw any definitive conclusions on this point is limited by the small number of animals tested.

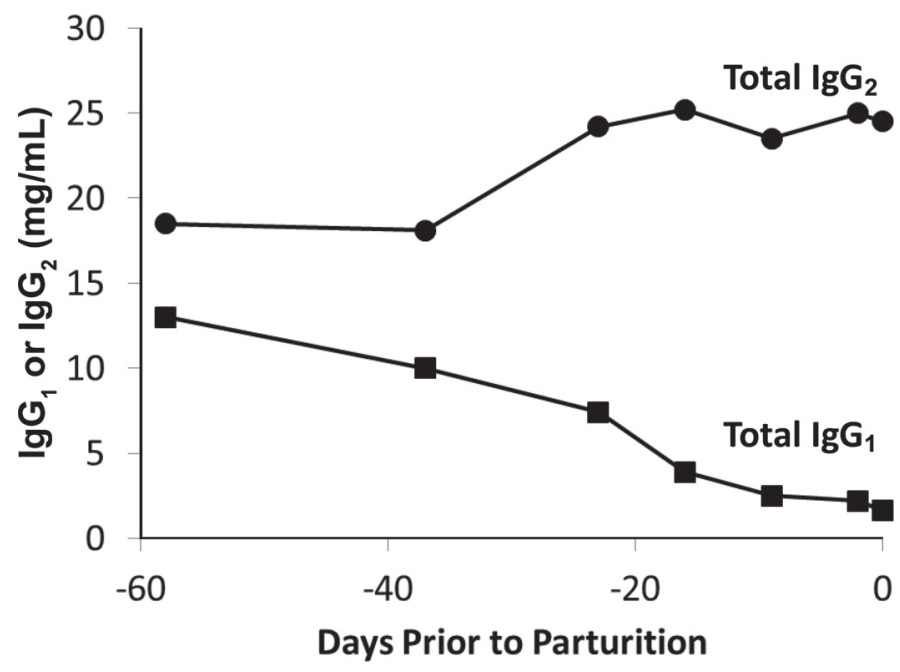

Figure 5. Total serum $\operatorname{IgG}_{1}$ and $\operatorname{IgG}_{2}$ concentrations over time in a representative animal (cow \#6003). Total $\mathrm{IgG}_{1}$ (squares) and $\mathrm{IgG}_{2}$ (circles) levels were measured for each serum time point using a commercially available ELISA kit.
These results highlight potential difficulties in using immunoassays to quantify antibody responses, as secondary antibodies may differ in their ability to recognize immunoglobulin from different allotypes. This is consistent with previous work noting that the molecular heterogeneity present in bovine $\operatorname{IgG}$, particularly in $\mathrm{IgG}_{2}$, can confound isotype-specific immunoassays (Butler et al., 1987a; Heyermann et al., 1992; Kacskovics and Butler, 1996).

\section{Confirmation of Isotype ELISA Results}

Liquid chromatography-tandem MS (LC/MS/MS) was selected as an analytical tool that was not dependent on immunoassay reagents and could be used to corroborate the isotype analysis. A serum sample and a colostrum sample were selected from a single cow (ear tag \#6003). The serum sample was collected on the day of parturition, and the colostrum sample was taken from the first milking on that same day. The IgG was purified by Protein $\mathrm{G}$ affinity chromatography and the $\mathrm{IgG}_{1} / \mathrm{IgG}_{2}$ isotype ratios were determined by LC/MS/ MS detection of isotype-specific peptides. Samples were analyzed by ELISA in parallel.

The isotype ELISA data on the Protein G-purified samples were consistent with the data shown above, indicating that the Protein $G$ chromatography does not significantly alter the relative proportions of $\operatorname{IgG}_{1}$ and $\mathrm{IgG}_{2}$ (Table 3). In the colostrum sample, $86 \%$ of the IgG was $\operatorname{IgG}_{1}$, whereas in the serum sample, $3 \%$ of the IgG was $\operatorname{IgG}_{1}$.

For the LC/MS/MS analysis, the Protein G-purified IgG samples were denatured, reduced, and alkylated, and then digested with endoproteinase Lys-C. The 
Table 2. Isotypes of recombinant human tumor necrosis factor (rhTNF)-binding antibodies present at peak serum titers for selected cows

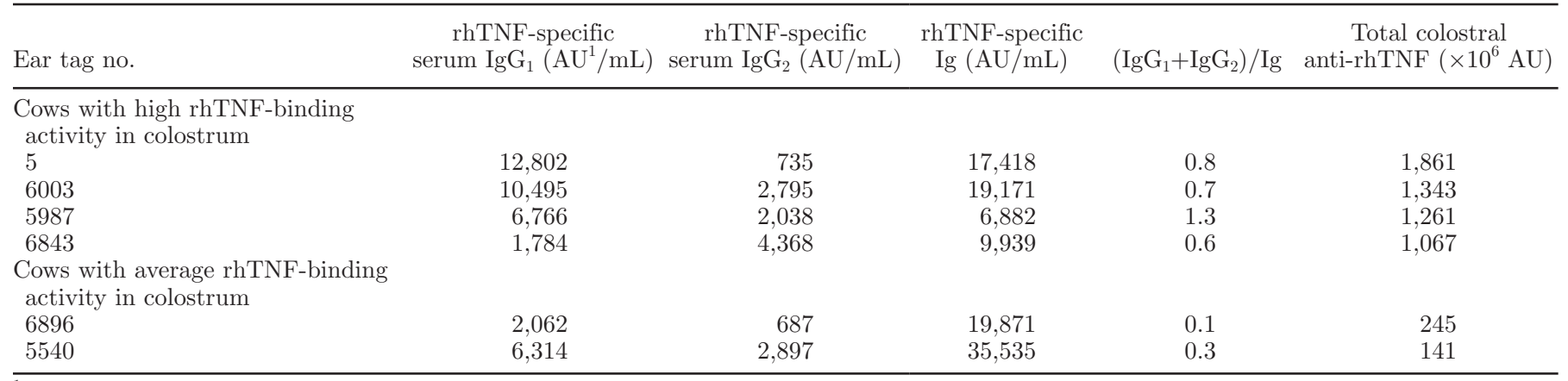

${ }^{1} \mathrm{AU}=$ arbitrary units.

resulting peptides were separated by reversed-phase HPLC, and analyzed with an in-line mass spectrometer. The intact mass of each peptide was measured, and the most abundant peptides observed in each peak were further analyzed by collision-induced dissociation, which produces characteristic fragments. The combination of the total peptide mass, along with the associated fragmentation pattern, allows for robust identification of the AA sequences of the most abundant peptides in a complex mixture (Keller et al., 2002). The peptide and fragment masses were compared against a sequence database from the National Center for Biotechnology Information (www.ncbi.nlm.nih.gov/protein). The strongest matches for the IgG samples were to sequences from bovine $\operatorname{IgG}_{2}$ (gi1699167; Kacskovics and Butler, 1996) and bovine $\operatorname{IgG}_{1}$ (gi108750; Symons et al., 1989), serving as internal validation of the purity of the samples and integrity of the analysis.

Three peptides were selected for detailed analysis, due to their strong signal in both experiments. The first, YAASSYLSLTGSDWK, is derived from the CL $\lambda$ domain, which is common to all bovine antibody isotypes. This peptide was used as an internal standard to confirm that roughly equal quantities of each sample were analyzed. The second, GPAREPQVYVLAPPQEELSK, is specific to the $\mathrm{CH} 3$ domain of the bovine
$\mathrm{IgG}_{1}$ isotype, and the third, GPAREPQVYVLDPPK, is the related peptide from the $\mathrm{IgG}_{2}$ isotype. Extracted ion chromatograms (Figure 6) were calculated using the expected masses for these peptides, and each peptide eluted as a single peak from the reverse-phase HPLC column. Peaks were integrated to estimate the relative abundance of light chain, $\operatorname{IgG}_{1}$ heavy chain, and $\operatorname{IgG}_{2}$ heavy chain (Table 3 ). The relative abundance of $\operatorname{IgG}_{1}$, estimated from these data using the CL peptide to normalize for sample loading concentration, is $\sim 7 \%$ for serum IgG and $\sim 90 \%$ for colostral IgG, in good agreement with the ELISA results for these samples (Table 3 ). This confirms that the isotype-specific immunoassay accurately reflects the molecular composition of the samples analyzed in this study.

\section{DISCUSSION}

This study set out to analyze the serum and colostrum antibody response to rhTNF in a cohort of 25 Holstein cows. This was part of a larger effort to optimize the production of rhTNF-specific antibody in colostrum to be used as the active ingredient in a human therapeutic for inflammatory bowel disease (Bhol et al., 2013; Harris et al., 2014). Substantial variability was seen in the specific colostral antibody response

Table 3. Isotype ELISA and LC/MS/MS data for a representative serum and colostrum sample

\begin{tabular}{|c|c|c|}
\hline Measurement & Serum $\operatorname{IgG}_{1}$ & Colostral $\mathrm{IgG}_{2}$ \\
\hline \multicolumn{3}{|l|}{ ELISA results } \\
\hline Total $\operatorname{IgG}_{1}^{3}(\mu \mathrm{g} / \mathrm{mL})$ & $2.1 \pm 0.1$ & $38.6 \pm 11.8$ \\
\hline Total $\operatorname{IgG}_{2}{ }^{3}(\mu \mathrm{g} / \mathrm{mL})$ & $71.2 \pm 6.6$ & $6.1 \pm 0.3$ \\
\hline$\% \mathrm{IgG}_{1}^{3}$ (ELISA) & $2.9 \pm 0.3$ & $86.3 \pm 3.7$ \\
\hline \multicolumn{3}{|l|}{ LC/MS/MS results } \\
\hline CL domain peptide peak area $\left(\times 10^{9}\right.$ ion counts $\times$ min $)$ & 21.5 & 25.6 \\
\hline $\mathrm{IgG}_{1} / \mathrm{CH} 3$ domain peptide peak area $\left(\times 10^{9}\right.$ ion counts $\left.\times \min \right)$ & 3.4 & 53.0 \\
\hline $\mathrm{IgG}_{2} / \mathrm{CH} 3$ domain peptide peak area $\left(\times 10^{9}\right.$ ion counts $\left.\times \min \right)$ & 45.6 & 6.0 \\
\hline Estimated $\% \mathrm{IgG}_{1}(\mathrm{LC} / \mathrm{MS} / \mathrm{MS})$ & $\sim 7$ & $\sim 90$ \\
\hline
\end{tabular}

${ }^{1}$ Data from final bleed (Dec. 18) from cow \#6003.

${ }^{2}$ Data from first milking (Dec 18) from cow \#6003.

${ }^{3}$ Values are reported as mean \pm standard deviation from triplicate measurements. 
following immunization with recombinant human TNF in the presence of a saponin-based adjuvant (Quil-A). Multiple elements likely contribute to this variabil-

\section{(A) YAASSYLSLTSSDWK (CL)}

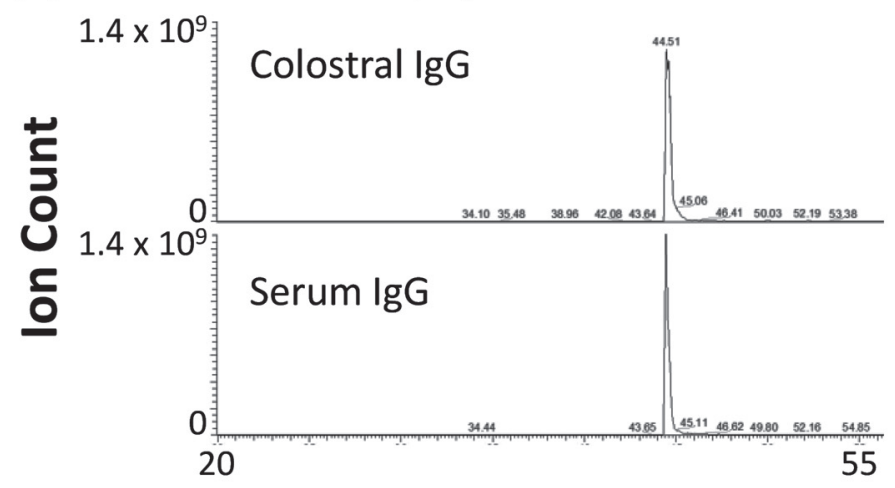

(B) GPAREPQVYVLAPPQEELSK (IgG1 CH3)

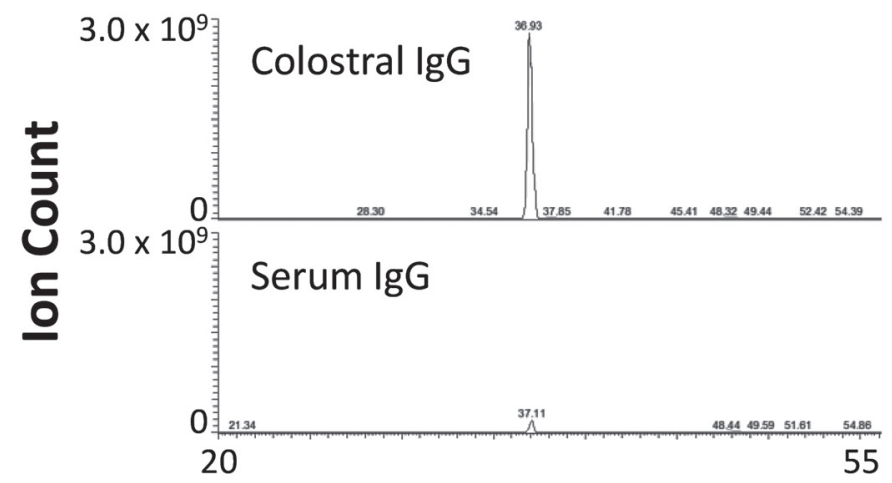

(C) GPAREPQVYVLDPPK (IgG2 CH3)

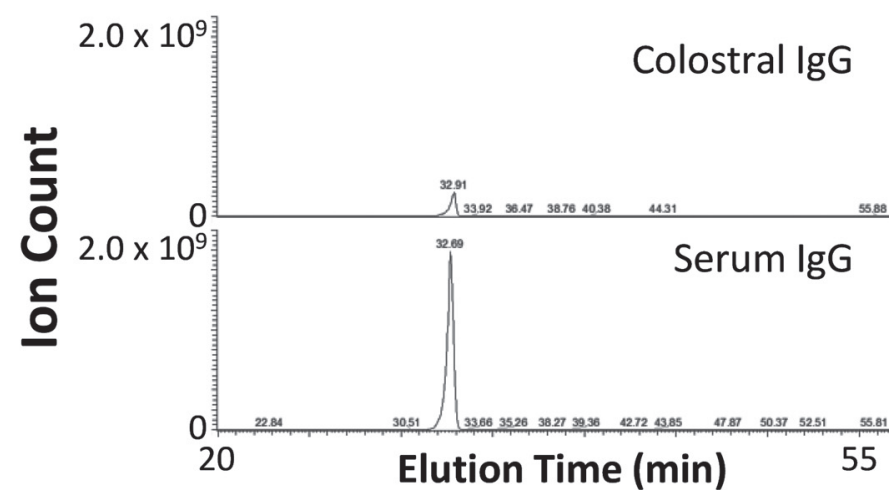

Figure 6. The IgG purified from cow \#6003 serum and colostrum was digested with Endoproteinase Lys-C and analyzed by liquid chromatography-tandem MS (LC/MS/MS). The total peptide masses and fragmentation patterns were matched against known protein sequences of bovine antibodies found in the National Center for Biotechnology Information nonredundant protein database. Extracted ion chromatograms are shown of peptides matching: (A) the constant light chain domain of the common bovine lambda light chain shared by all isotypes, (B) the $\mathrm{CH} 3$ domain of bovine $\mathrm{IgG}_{1}$, and $(\mathrm{C})$ the $\mathrm{CH} 3$ domain of bovine $\mathrm{IgG}_{2}$. ity. First, the overall immune response varies between animals, even in genetically identical, in-bred strains (Davern et al., 1987). Second, the dominant isotype of the antibody response can also vary, depending on geographic location (Thompson-Crispi and Mallard, 2012), route of antigen administration (Boerhout et al., 2015), and the presence of additional proteins that stimulate the B cells to preferentially class-switch to certain isotypes (Estes et al., 1998). It is possible that rhTNF itself could affect the isotype distribution (Manoj et al., 2004), but it is unclear if human TNF will crossreact with the bovine receptors. Third, the timing of the immunizations relative to parturition could have an effect, as the peak serum titers would optimally appear in the time just before calving when the rate of immunoglobulin transfer to the colostrum is maximal (Gross et al., 2014). Finally, all of the cows received several health vaccinations $21 \mathrm{~d}$ before the first TNF injection. These vaccinations are standard veterinary care, but it is possible that the proximity of the vaccinations to the immunizations and parturition may have influenced the variability in immune responses we observed in this study.

We found a subset of high-producing animals within our cohort (4 out of 25 cows) that had average serum antibody levels, but levels of antigen-specific colostral antibody that were outside of the expected range. We were unable to definitively identify the elements that contribute to this high colostral antibody response. Further work will be needed to determine if this trait is heritable, or a reflection of environmental factors that may affect the concentrations of hormones that regulate colostrogenesis (Gross et al., 2014), and whether it is reproducible across multiple lactations.

The remaining cows had a normal distribution of anti-rhTNF antibody titers in both colostrum and serum. The anti-rhTNF antibody levels in the 2 compartments were poorly correlated, suggesting that the variability in colostrum anti-rhTNF levels is a function of multiple elements: variable immune responses in the animals, the timing of the immunizations relative to parturition, and differences in the efficiency of antibody transport into the colostrum. The lack of a strong correlation between colostral anti-rhTNF titers and parameters related to any one of these features suggests that none of these sources of potential variation are dominant, and all may contribute. A detailed assessment of the relative contributions of serum response, timing of immunizations, and transport efficiency will require a more sophisticated statistical analysis, and likely a much greater sample size.

As part of this study, total serum $\operatorname{IgG}_{1}$ and $\operatorname{IgG}_{2}$ levels were measured in the weeks leading up to parturition. Serum $\operatorname{IgG}_{2}$ levels were found to be in the 
expected range of 10 to $30 \mathrm{mg} / \mathrm{mL}$ and did not change significantly over time. Serum levels of $\operatorname{IgG}_{1}$ were found to decrease dramatically before parturition. It has been known for some time that $\operatorname{IgG}_{1}$ is preferentially transported into colostrum, but a previous report (Sasaki et al., 1976) described a relatively modest drop in serum levels of $35 \%$ rather than the $84 \%$ described here. We believe it is unlikely that the substantial $\mathrm{IgG}_{1}$ decrease resulted from activity of the human TNF introduced during immunization. The cows received very low doses of TNF (50 $\mu \mathrm{g}$ per injection, or less than $100 \mathrm{ng} / \mathrm{kg}$ ), and the immunization regimen had no measurable effect on the health of the cows or calves. Although it is possible that these differences reflect differences in the cohorts of animals tested, it is also possible that it reflects experimental differences in analytical methodologies. Accurate quantitation of bovine antibody isotypes using immunoassays is complicated by the effect of allotypic and idiotypic variation (Butler et al., 1987b). This is the first study to confirm the isotype distributions in colostrum and serum using mass spectrometry.

We estimate that a total of 50 to $500 \mathrm{~g}$ of $\mathrm{IgG}_{1}$ is removed from the serum before parturition and $80-800 \mathrm{~g}$ of total $\mathrm{IgG}$ (which is $\sim 90 \% \mathrm{IgG}_{1}$ ) appears in the first milking (Supplemental Table S2; http:// dx.doi.org/10.3168/jds.2016-10863). This suggests that increased production of $\mathrm{IgG}_{1}$ occurred to partially compensate for the transfer to colostrum. In earlier studies, Sasaki et al. (1976) used radiolabeled $\mathrm{IgG}_{1}$ and $\mathrm{IgG}_{2}$ to track the kinetics of immunoglobulin production and transfer to colostrum in a group of 4 cows. They found that the increase in production of serum $\operatorname{IgG}_{1}$ almost completely compensated for the losses due to colostrogenesis. The serum $\operatorname{IgG}_{1}$ concentration at any point in time represents a balance between antibody production in plasma cells and clearance through either degradation or transfer into mammary gland for incorporation into colostrum. The profound decrease in serum $\operatorname{IgG}_{1}$ observed in our animals 1 to 2 wk before parturition implies either a relatively less efficient production of $\mathrm{IgG}_{1}$ or a more efficient translocation into the udder than has been previously reported in the literature.

\section{CONCLUSIONS}

This study set out to analyze the serum and colostrum antibody response to rhTNF in a cohort of 25 Holstein cows. This was part of a larger effort to optimize the production of rhTNF-specific antibody in colostrum to be used as the active ingredient in a human therapeutic for inflammatory bowel disease (Bhol et al., 2013; Harris et al., 2014). Three observations were made that are of scientific and practical importance. First, substantial variability was found in antibody titers across animals, both in serum and colostrum. Although not unexpected, these data highlight the importance of using adequate numbers of animals in any study examining immunization regimens in an outbred animal population. Second, antibody titers in serum did not always correlate with antibody levels in colostrum, highlighting the difficulty of using a serum immune response to predict the quality of hyperimmune colostrum. Third, the drop in serum $\operatorname{IgG}_{1}$ levels at parturition was much larger than has been reported in the literature.

\section{ACKNOWLEDGMENTS}

This work was funded by Avaxia Biologics Inc. (Lexington, MA).

\section{REFERENCES}

Ashraf, H., D. Mahalanabis, A. K. Mitra, S. Tzipori, and G. J. Fuchs, 2001. Hyperimmune bovine colostrum in the treatment of shigellosis in children: A double-blind, randomized, controlled trial. Acta Paediatr. 90:1373-1378.

Barrington, G. M., T. E. Besser, W. C. Davis, C. C. Gay, J. J. Reeves, and T. B. McFadden. 1997. Expression of immunoglobulin G1 receptors by bovine mammary epithelial cells and mammary leukocytes. J. Dairy Sci. 80:86-93. http://dx.doi.org/10.3168/jds. S0022-0302(97)75915-0.

Baumrucker, C. R., A. M. Burkett, A. L. Magliaro-Macrina, and C. D. Dechow. 2010. Colostrogenesis: mass transfer of immunoglobulin G1 into colostrum. J. Dairy Sci. 93:3031-3038. http://dx.doi. org $/ 10.3168 /$ jds.2009-2963.

Baumrucker, C. R., and R. M. Bruckmaier. 2014. Colostrogenesis: IgG1 transcytosis mechanisms. J. Mammary Gland Biol. Neoplasia 19:103-117. http://dx.doi.org/10.1007/s10911-013-9313-5.

Bhol, K. C. D. E. Tracey, B. R. Lemos, G. D. Lyng, E. C. Erlich, D. M. Keane, M. S. Quesenberry, A. D. Holdorf, L. D. Schlehuber, S. A. Clark, and B. S. Fox. 2013. AVX-470: A novel oral anti-TNF antibody with therapeutic potential in inflammatory bowel disease. Inflamm. Bowel Dis. 19:2273-2281.

Boerhout, E., M. Vrieling, L. Benedictus, I. Daemen, L. Ravesloot, V. Rutten, P. Nuijten, J. van Strijp, A. Koets, and S. Eisenberg. 2015. Immunization routes in cattle impact the levels and neutralizing capacity of antibodies induced against $S$. aureus immune evasion proteins. Vet. Res. 46:115 http://dx.doi.org/10.1186/s13567015-0243-7.

Brunser, O., J. Espinoza, G. Figueroa, M. Araya, E. Spencer, H. Hilpert, H. Link-Amster, and H. Brüssow. 1992. Field trial of an infant formula containing anti-rotavirus and anti-Escherichia coli milk antibodies from hyperimmunized cows. J. Pediatr. Gastroenterol. Nutr. 15:63-72.

Brüssow, H., H. Hilpert, I. Walther, J. Sidoti, C. Mietens, and P. Bachmann. 1987. Bovine milk immunoglobulins for passive immunity to infantile rotavirus gastroenteritis. J. Clin. Microbiol. 25:982-986.

Butler, J. E., M. V. Borca, H. Heyermann, M. Dillender, and M. Bielecka. 1987a. The heterogeneity of bovine IgG2-III. The ion-exchange heterogeneity of IgG2a is the result of VH-region variation. Mol. Immunol. 24:1317-1326. http://dx.doi.org/10.1016/0161$5890(87) 90127-1$.

Butler, J. E., H. Heyermann, M. Borca, M. Bielecka, and L. V. Frenyo. 1987b. The isotypic, allotypic and idiotypic heterogeneity of bovine IgG2. Vet. Immunol. Immunopathol. 17:1-16. http://dx.doi. org/10.1016/0165-2427(87)90122-X

Coelho, A. L. M., R. F. D. C. Vieira, M. R. Gasparini, J. L. Garcia, O. Vidotto, and M. C. Vidotto. 2013. Immune response of calves immunized with cocktail of DNA vaccine encoding complexed outer membrane proteins from Anaplasma marginale. Se- 
min. Ciências Agrárias 34:3877 http://dx.doi.org/10.5433/16790359.2013v34n6Supl2p3877.

Davern, K. M., W. U. Tiu, G. Morahan, M. D. Wright, E. G. Garcia, and G. F. Mitchell. 1987. Responses in mice to Sj26, a glutathione S-transferase of Schistosoma japonicum worms. Immunol. Cell Biol. 65:473-482. http://dx.doi.org/10.1038/icb.1987.56.

Estes, D. M., W. Tuo, W. C. Brown, and J. Goin. 1998. Effects of type I/type II interferons and transforming growth factor-beta on B-cell differentiation and proliferation. Definition of costimulation and cytokine requirements for immunoglobulin synthesis and expression. Immunology 95:604-611. http://dx.doi.org/10.1046/j.13652567.1998.00645.x.

FASS Inc. 2010. Guide for the care and use of agricultural animals in research and teaching. 3rd ed. FASS Inc., Champaign, IL.

Gross, J. J., E. C. Kessler, V. Bjerre-Harpoth, C. Dechow, C. R. Baumrucker, and R. M. Bruckmaier. 2014. Peripartal progesterone and prolactin have little effect on the rapid transport of immunoglobulin G into colostrum of dairy cows. J. Dairy Sci. 97:29232931. http://dx.doi.org/10.3168/jds.2013-7795.

Harris, M. S., D. Hartman, S. Spence, S. Kennedy, T. Ptak, R. Pruitt, S. Vermeire, and B. S. Fox. 2014. AVX-470, an orally delivered anti-TNF antibody for treatment of acute ulcerative colitis: Results of a first-in-human trial. United European Gastroenterol. J. 2:A65.

Heyermann, H., J. E. Butler, and B. Frangione. 1992. The heterogeneity of bovine IgG2 - V. Differences in the primary structure of bovine IgG2 allotypes. Mol. Immunol. 29:1147-1152. http://dx.doi. org/10.1016/0161-5890(92)90048-3.

Jackson, L. A., and J. P. Opdebeeck. 1995. The effect of various adjuvants on the humoral immune response of sheep and cattle to soluble and membrane midgut antigens of Boophilus microplus. Vet. Parasitol. 58:129-141.

Kacskovics, I., and J. E. Butler. 1996. The heterogeneity of bovine IgG2-VIII. The complete cDNA sequence of bovine IgG2a (A2) and an IgG1. Mol. Immunol. 33:189-195. http://dx.doi. org/10.1016/0161-5890(95)00107-7.

Kateregga, J., G. W. Lubega, E. B. Lindblad, E. Authié, T. H. T. Coetzer, and A. F. V. Boulangé. 2012. Effect of adjuvants on the humoral immune response to congopain in mice and cattle. BMC Vet. Res. 8:63. http://dx.doi.org/10.1186/1746-6148-8-63.

Keller, A., A. I. Nesvizhskii, E. Kolker, and R. Aebersold. 2002. Empirical statistical model to estimate the accuracy of peptide identifications made by MS/MS and database search. Anal. Chem. 74:5383-5392.

Kramski, M., R. J. Center, A. K. Wheatley, J. C. Jacobson, M. R. Alexander, G. Rawlin, and D. F. Purcell. 2012. Hyperimmune bovine colostrum as a low-cost, large-scale source of antibodies with broad neutralizing activity for HIV-1 envelope with potential use in microbicides. Antimicrob. Agents Chemother. 56:4310-4319.

Manoj, S., P. J. Griebel, L. A. Babiuk, and S. van Drunen Littel-van den Hurk. 2004. Modulation of immune responses to bovine herpesvirus-1 in cattle by immunization with a DNA vaccine encoding glycoprotein D as a fusion protein with bovine CD154. Immunology 112:328-338. http://dx.doi.org/10.1111/j.1365-2567.2004.01877.x.

Maue, A. C., W. R. Waters, M. V. Palmer, D. L. Whipple, F. C. Minion, W. C. Brown, and D. M. Estes. 2004. CD80 and CD86, but not CD154, augment DNA vaccine-induced protection in experimental bovine tuberculosis. Vaccine 23:769-779. http://dx.doi. org/10.1016/j.vaccine.2004.07.019.

NRC. 2011. Guide for the care and use of laboratory animals. 8th ed. The National Academies Press, Washington, DC.

Opdebeeck, J. P., J. Y. Wong, L. A. Jackson, and C. Dobson. 1988. Vaccines to protect Hereford cattle against the cattle tick, Boophilus microplus. Immunology 63:363-367.

Opekun, A. R., H. M. El-Zaimaity, M. S. Osato, M. A. Gilger, H. M. Malaty, M. Terry, D. R. Headon, and D. Y. Graham. 1999. Novel therapies for Helicobacter pylori infection. Aliment. Pharmacol. Ther. 13:35-42.

Ostensson, K., and S. Lun. 2008. Transfer of immunoglobulins through the mammary endothelium and epithelium and in the local lymph node of cows during the initial response after intramammary challenge with E. coli endotoxin. Acta Vet. Scand. 50:26. http:// dx.doi.org/10.1186/1751-0147-50-26.

Otto, W., B. Najnigier, T. Stelmasiak, and R. M. Robins-Browne. 2011. Randomized control trials using a tablet formulation of hyperimmune bovine colostrum to prevent diarrhea caused by enterotoxigenic Escherichia coli in volunteers. Scand. J. Gastroenterol. 46:862-868. http://dx.doi.org/10.3109/00365521.2011.574726.

Press, W. H., S. A. Teukolsky, W. T. Vetterling, and B. P. Flannery. 1992. Numerical Recipes in C. 2nd ed. Press Syndicate of the University of Cambridge, New York, NY.

Rajput, Z. I., S. Hu, C. Xiao, and A. G. Arijo. 2007. Adjuvant effects of saponins on animal immune responses. J. Zhejiang Univ. Sci. B 8:153-161. http://dx.doi.org/10.1631/jzus.2007.B0153.

Sasaki, M., C. L. Davis, and B. L. Larson. 1976. Production and turnover of IgG1 and IgG2 immunoglobulins in the bovine around parturition. J. Dairy Sci. 59:2046-2055. http://dx.doi.org/10.3168/ jds.S0022-0302(76)84486-4.

Smolenski, G. A., M. K. Broadhurst, K. Stelwagen, B. J. Haigh, and T. T. Wheeler. 2014. Host defence related responses in bovine milk during an experimentally induced Streptococcus uberis infection. Proteome Sci. 12:19. http://dx.doi.org/10.1186/1477-5956-12-19.

Steele, J., J. Sponseller, D. Schmidt, O. Cohen, and S. Tzipori. 2013 Hyperimmune bovine colostrum for treatment of GI infections: A review and update on Clostridium difficile. Hum. Vaccin. Immunother. 9:1565-1568. http://dx.doi.org/10.4161/hv.24078.

Symons, D. B., C. A. Clarkson, and D. Beale. 1989. Structure of bovine immunoglobulin constant region heavy chain gamma 1 and gamma 2 genes. Mol. Immunol. 26:841-850. http://dx.doi. org/10.1016/0161-5890(89)90140-5.

Thompson-Crispi, K. A., and B. A. Mallard. 2012. Type 1 and type 2 immune response profiles of commercial dairy cows in 4 regions across Canada. Can. J. Vet. Res. 76:120-128.

Thompson-Crispi, K. A., M. Sargolzaei, R. Ventura, M. Abo-Ismail, F. Miglior, F. Schenkel, and B. A. Mallard. 2014. A genome-wide association study of immune response traits in Canadian Holstein cattle. BMC Genomics 15:559. http://dx.doi.org/10.1186/14712164-15-559.

Tracey, D., L. Klareskog, E. H. Sasso, J. G. Salfeld, and P. P. Tak. 2008. Tumor necrosis factor antagonist mechanisms of action: A comprehensive review. Pharmacol. Ther. 117:244-279. http:// dx.doi.org/10.1016/j.pharmthera.2007.10.001

van Dissel, J. T., M. De Groot, C. M. H. Hensgens, S. Numan, E. J. Kuijper, P. Veldkamp, and J. Van't Wout. 2005. Bovine antibodyenriched whey to aid in the prevention of a relapse of Clostridium difficile-associated diarrhoea: Preclinical and preliminary clinical data. J. Med. Microbiol. 54:197-205. http://dx.doi.org/10.1099/ jmm.0.45773-0.

van Drunen Littel-van den Hurk, S., Z. Lawman, M. Snider, D. Wilson, J. V. van den Hurk, B. Ellefsen, and D. Hannaman. 2013 Two doses of bovine viral diarrhea virus DNA vaccine delivered by electroporation induce long-term protective immune responses. Clin. Vaccine Immunol. 20:166-173. http://dx.doi.org/10.1128/ CVI.00565-12

van Drunen Littel-van den Hurk, S., A. Luxembourg, B. Ellefsen, D. Wilson, A. Ubach, D. Hannaman, and J. V. van den Hurk. 2008. Electroporation-based DNA transfer enhances gene expression and immune responses to DNA vaccines in cattle. Vaccine 26:55035509. http://dx.doi.org/10.1016/j.vaccine.2008.07.093. 